\title{
Proanthocyanidins inhibit hydrolysis of leaf proteins by rumen microflora in vitro
}

\author{
BY GREGORY J. TANNER*, ANDREW E. MOORE AND PHILIP J. LARKIN \\ Division of Plant Industry, Commonwealth Scientific and Industrial Research Organization, \\ GPO Box 1600, Canberra, Australia
}

(Received 20 May 1993 - Revised 10 September 1993 - Accepted 23 September 1993)

\begin{abstract}
Proanthocyanidins (condensed tannins; PA) purified from the leaves of forage legumes Trifolium arvense, Lotus pedunculatus, Lotus corniculatus, Dorycnium rectum, Coronilla varia, Onobrychis viciifolia, or Hedysarum coronarium, were added to soluble lucerne (Medicago sativa) leaf protein and incubated with strained rumen fluid in vitro. Fractions were collected and frozen immediately. Denatured proteins were fractionated by sodium dodecylsulphate-polyacrylamide gel electrophoresis (SDS-PAGE), stained, and relative levels were quantified by densitometry. In the absence of PA the large subunit (LSU) of ribulose bisphosphate carboxylase $(E C$ 4.1.1.39) was susceptible to proteolysis by rumen microflora but the small subunit (SSU) resisted breakdown. PA purified from Onobrychis was added to soluble leaf protein, at PA: protein ratios between $1: 1$ and $1: 20$. The rate of proteolysis of LSU was significantly reduced at $P A$ :protein ratios of $1: 2$ and $1: 1(P<0.001)$ and the rate of digestion was reduced by between 3- and 21-fold. In separate experiments PA isolated from the range of species described was added to rumen fluid to give $P A$ :protein ratios of 1:5. The addition of $P A$ significantly reduced the rate of proteolysis of LSU, when compared with PA-free control. There were only small differences between PA from different species. The inhibitory effect of PA may have been due to PA binding to the dietary protein or to the rumen proteases, interfering with the action of proteases on susceptible sites within the substrate.
\end{abstract}

Condensed tannins: Proanthocyanidins: Rumen microflora: In vitro proteolysis

Diets containing proanthocyanidins (PA) reduce the stability of protein foam in the rumen, conferring bloat safety as well as improving the efficiency of protein utilization in ruminants (Rumbaugh, 1985). Forages containing up to $110 \mathrm{~g} \mathrm{PA} / \mathrm{kg}$ dry matter (DM) increase the duodenal absorption of non-ammonia $\mathrm{N}$ in ruminants, resulting in faster lean weight gain (Barry \& Manley, 1984; Purchas \& Keogh, 1984; Barry et al. 1986 b). However, diets of forages with high levels of PA ( $>110 \mathrm{~g} / \mathrm{kg} \mathrm{DM}$ ) may result in decreased voluntary intake, digestibility, and adipose deposition (Barry \& Duncan, 1984; Barry \& Manley, 1986; Chiquette et al. 1988; Van Hoven \& Furstenburg, 1992). When the adverse effects of high levels of reactive PA are moderated by the addition of dietary polyethylene glycol, both intake and digestibility are improved (Barry et al. 1986a).

PA binds to proteins by means of hydrogen bonding and hydrophobic interaction (Zucker, 1983; Spencer et al. 1988a) and this may interfere with the digestion of proteins or lead to precipitation. Low concentrations of PA stimulate the rate of tryptic digestion of bovine serum albumin, while high concentrations inhibit tryptic hydrolysis (Mole \& Waterman, 1985). Extracts of carob containing PA have been reported to decrease the rate of casein hydrolysis by rumen microfiora (Tagari et al..1965). PA purified from Lespedeza cuneata inhibited cellulases non-competitively (Petersen \& Hill, 1991). The protein-

\footnotetext{
* For reprints.
} 
precipitating capacity and the degree of in vitro inhibition of trypsin (EC 3.4.21.4), $\alpha$ amylase $(E C$ 3.2.1.1) and lipase $(E C$ 3.1.1.3) increased with increasing degree of polymerization of PA purified from fodder plants (Horigome et al. 1988). High PA strains of Lotus corniculatus had reduced rates of DM digestion compared with low PA strains using in vitro and in sacco techniques (Chiquette et al. 1988). However, there is no information on the effect of PA isolated from forage legumes on proteolysis by rumen microflora in vitro.

The aim of these experiments was to investigate the effect of the concentration of PA purified from Onobrychis on the rate of hydrolysis of the large subunit (LSU) and the small subunit (SSU) of ribulose bisphosphate carboxylase (Rubisco, EC 4.1.1.39; soluble leaf protein) by rumen microflora in vitro. The effect of different PA purified from other legumes and added at the same concentration was also examined.

\section{METHODS}

\section{Preparation of soluble leaf protein}

All operations were carried out at $4^{\circ}$ unless otherwise stated. Young, fully expanded Medicago sativa (lucerne) leaves $(20 \mathrm{~g})$ were chilled, macerated in $100 \mathrm{ml}$ grinding buffer (25 mM-Tris- $\mathrm{HCl}, \mathrm{pH} 6.8$ ), which contained $1 \mathrm{~mm}$-phenylmethylsulphonyl fluoride (Gray, 1982) and $0.5 \mathrm{mM}-\mathrm{Na}_{2}$ EDTA. The homogenate was filtered through mirrorcloth, and the $\mathrm{pH}$ re-adjusted to 6.8 with $1 \mathrm{M}-\mathrm{KOH}$. The filtrate was centrifuged at $10000 \mathrm{~g}$ for $15 \mathrm{~min}$. Solid $\left(\mathrm{NH}_{4}\right)_{2} \mathrm{SO}_{4}$ was added to the supernatant fraction to give $80 \%$ saturation, stirred for $30 \mathrm{~min}$, and centrifuged at $10000 \mathrm{~g}$ for $15 \mathrm{~min}$. The pellet was resuspended in $5-7 \mathrm{ml}$ dialysis buffer $(100 \mathrm{ml}$ grinding buffer $/ 1)$, and dialysed overnight. The dialysate was centrifuged, and portions of the supernatant fraction stored at $-15^{\circ}$.

\section{Purification of $P A$}

PA were purified from leaves of several representative forage legume tribes including Trifoleae (Trifolium arvense), Loteae (Lotus pedunculatus, Lotus corniculatus, and Dorycnium rectum), Coronilliae (Coronilla varia), and Hedysareae (Onobrychis viciifolia, Hedysarum coronarium). All operations were carried out at $4^{\circ}$ and care was taken to exclude light wherever possible. About $100 \mathrm{~g}$ mature leaf material was ground and PA extracted and washed as described by Jones et al. (1976), except that the crude PA preparation was also washed with ethyl acetate. PA was purified on Sephadex LH20, also following the method of Jones et al. (1976), lyophilized and stored at $-15^{\circ}$, protected from light and moisture. The yield of PA was between 1 and $2 \mathrm{~g}$ white powder $/ \mathrm{kg}$ fresh leaf material. About $15 \%$ of the vanillin-HCl-positive material in the crude extract was recovered in the freeze-dried material. PA preparations from different species gave similar results during chromatography on Sephadex LH20. The PA ran as a single band when analysed by paper chromatography, TLC or HPLC (Mabry et al. 1970; Kristiansen, 1984).

\section{Preparation of strained rumen fluid}

A Border Leicester $\times$ Merino adult male castrate sheep was maintained on a diet of pelleted lucerne hay for at least 2 weeks before the experiments. Fluid was collected from a rumen fistula after an overnight fast, quickly strained through a layer of nylon cloth to remove undigested plant material, and diluted with nine volumes of McDougall's (1948) artificial saliva. During these manipulations the rumen fluid and buffers were maintained under $\mathrm{CO}_{2}$ at $39^{\circ}$. 


\section{In vitro rumen digestion}

Localization and stability of the proteolytic activity in strained rumen fluid. Casein solution was thawed and $60 \mu \mathrm{l}$ portions containing $3 \mathrm{mg}$ protein were added to glass tubes. The digestion was initiated by the addition of strained rumen fluid. The location of the proteolytic activity was examined by the addition of $2 \mathrm{ml}$ either strained rumen fluid, or rumen fluid that had been centrifuged at $5000 \mathrm{~g}$ for $10 \mathrm{~min}$ and then filtered through a $0.4 \mu \mathrm{m}$ filter. The stability of the proteolytic activity was examined by the addition of $2 \mathrm{ml}$ strained rumen fluid which had been stored under $\mathrm{CO}_{2}$ at $39^{\circ}$ for either, 1, 2, or $4 \mathrm{~h}$. The digestion mixtures were flushed with $\mathrm{CO}_{2}$ and maintained under $\mathrm{CO}_{2}$ using bunsen valves, and incubated at $39^{\circ}$. Controls contained casein and $2 \mathrm{ml}$ either McDougall's (1948) artificial saliva or strained rumen fluid that had been boiled. Portions $(100 \mu \mathrm{l})$ were withdrawn from the digestion mixtures after $1 \mathrm{~h}$ and $2 \mathrm{~h}$, added to $100 \mu \mathrm{l}$ sodium dodecylsulphate (SDS) buffer containing carbonic anhydrase (CA; EC 4.2.1 .1, Sigma) as an internal protein standard and snap frozen in liquid $\mathrm{N}_{2}$ immediately to prevent further proteolysis. The SDS buffer contained $155 \mathrm{~mm}$-Tris-- $\mathrm{HCl}, \mathrm{pH} 68$, plus (g/1): glycerol 300 , SDS 100, mercapto-ethanol 33.4, and bromophenol blue $25 \mathrm{mg}$. Where indicated $200 \mathrm{mg} \mathrm{CA} / 1$ was also added to the SDS buffer as an internal standard.

The effect of added $P A$ on the hydrolysis of leaf protein by strained rumen fluid. Soluble leaf protein was thawed and $60 \mu \mathrm{l}$ portions, containing $3 \mathrm{mg}$ protein, were added to glass tubes. Lyophilized PA was dissolved in water and added to the protein solution and the total volume adjusted to $100 \mu \mathrm{l}$ with water. One digestion was carried out for each PA concentration. Two experiments were conducted and repeated on successive weeks to measure (a) the effect of the concentration of Onobrychis PA on the rate of protein hydrolysis (Expts 1 and 2) or (b) the effect of PA isolated from different species (Expts 3 and 4). For experiments with the concentration of Onobrychis PA the PA:protein ratio was varied between $1: 1$ and $1: 20$. In experiments where the effects of PA from different species were compared the PA:protein ratio was fixed at 1:5. A visible precipitate formed immediately on the addition of PA. The digestion was initiated by the addition of $2 \mathrm{ml}$ strained rumen fluid. The digestion mixtures were flushed with $\mathrm{CO}_{2}$, and maintained under an atmosphere of $\mathrm{CO}_{2}$ using bunsen valves and incubated at $39^{\circ}$. The final $\mathrm{pH}$ of digestion mixtures under these conditions was $6 \cdot 8$.

Portions of $100 \mu \mathrm{l}$ were taken from digestion tubes at $15 \mathrm{~min}$ intervals for $2 \mathrm{~h}$ and added to $100 \mu \mathrm{l}$ SDS buffer containing $\mathrm{CA}$ and snap frozen in liquid $\mathrm{N}_{2}$. Control digestions containing $3 \mathrm{mg}$ either bovine serum albumin (resistant to rumen digestion), or casein (susceptible to rumen digestion), in $100 \mu$ dialysis buffer, and $2 \mathrm{ml}$ strained rumen fluid, were included in each experiment, as well as a control digestion containing strained rumen fluid only.

\section{SDS-polyacrylamide gel electrophoresis (SDS-PAGE)}

On completion of each experiment, frozen portions were thawed and denatured in a boiling water bath for $4 \mathrm{~min}$. Proteins were fractionated by SDS-PAGE using a modification of the Laemmli \& Favre (1973) procedure. The gels $(1.5 \times 140 \times 120 \mathrm{~mm})$ consisted of a separating gel ( $123 \mathrm{~g} / \mathrm{l}$ total acrylamide, $20 \mathrm{~g} / \mathrm{kg}$ bisacrylamide : total acrylamide), containing $375 \mathrm{~mm}-$ Tris- $\mathrm{HCl}, \mathrm{pH} 8 \cdot 4$, plus $(\mathrm{g} / 1)$ : acrylamide 120 , bisacrylamide $2 \cdot 6$, degassed and polymerized with SDS 1, ammonium persulphate (APS) 0.13 , and tetramethyl ethylene diamine (TEMED) $0 \cdot 85$. A $35 \mathrm{~mm}$ stacking gel ( $30 \mathrm{~g} / 1$ total acrylamide, $20 \mathrm{~g} / \mathrm{kg}$ bisacrylamide : total acrylamide), was cast above the separating gel. The stacking gel contained $560 \mathrm{~mm}$-Tris$\mathrm{HCl}$, pH 6.8, plus (g/l): acrylamide 30 , bisacrylamide 0.66 which was degassed and polymerized with APS $0 \cdot 5$, SDS 1 and TEMED $0 \cdot 78$. Portions $(5 \mu l)$ of the denatured protein samples were separated by electrophoresis at $35 \mathrm{~mA}$ for $4 \mathrm{~h}$. The gels were washed twice 
with destaining solution (glacial acetic acid-methanol-water, 7:30:63, by vol.) over $1 \mathrm{~h}$ to remove SDS, and then stained for $1 \mathrm{~h}$ in Coomassie Brilliant Blue R250, $5 \mathrm{~g} / \mathrm{l}$ in a solution containing glacial acetic acid-ethanol-water $(25: 40: 35$, by vol.). Excess stain was removed by soaking in destaining solution.

Protein bands were quantified by densitometry, and the amount of LSU remaining in each lane was calculated from the area under the LSU densitometer trace. The areas under the densitometer traces of the internal standard (CA) on a gel were averaged and the CA area within a lane: average CA area for the gel ratio was multiplied by the LSU area for that lane to give an adjusted LSU area. This was done to correct the LSU area for small variations in the final width of lanes. When different gels from one experiment were compared there were slight differences in the staining of gels. This was corrected for by multiplying the adjusted LSU area by the ratio of the average CA areas on the gel to the CA areas averaged over all gels, to give the normalized LSU area.

For each digestion a simple linear regression of $\log _{e}$ (normalized LSU area) $v$. time best fitted the data, indicating that the rate of hydrolysis followed simple first order kinetics. The slope of that regression gave the rate of hydrolysis and the standard error of the slope was calculated. All analyses were performed using Genstat (Numerical Algorithms Group Inc.).

\section{RESULTS}

Protection of casein by Onobrychis $P A$ during in vitro rumen digestion

Bovine serum albumin resisted proteolysis for at least $4 \mathrm{~h}$, while casein was largely degraded within $15 \mathrm{~min}$, and undetectable after incubation for $1 \mathrm{~h}$ in strained rumen fluid (Plate 1). The control digestion mixture, which contained rumen fluid only, did not accumulate any bands on the SDS-PAGE gel. The addition of purified Onobrychis PA, to give a PA: protein ratio of $1: 2$, reduced the rate of casein hydrolysis. In the presence of PA, substantial amounts of both $\alpha$ - and $\beta$-casein remained after $1 \mathrm{~h}$, and detectable amounts were observed after incubation in strained rumen fluid for $2 \mathrm{~h}$ (Plate 1).

\section{Localization and stability of the proteolytic activity}

The hydrolysis of these proteins was due to enzyme activity in the strained rumen fluid. Casein incubated in the presence of buffer or boiled rumen fluid remained undegraded (Plate 2). The proteolytic activity was associated with the particulate fraction of the rumen fluid. Casein remained undegraded after $2 \mathrm{~h}$ when incubated in the presence of strained rumen fluid that had been centrifuged at $5000 \mathrm{~g}$ for $10 \mathrm{~min}$ followed by filtration through a $0.4 \mu \mathrm{m}$ filter (Plate 2).

The proteolytic activity remained stable over the period of the digestions. Casein was completely hydrolysed after incubation for $1 \mathrm{~h}$ in strained rumen fluid that had been stored for up to $4 \mathrm{~h}$ under $\mathrm{CO}_{2}$ at $39^{\circ}$ (Plate 2).

\section{Protection of $L S U$ by Onobrychis $P A$ during in vitro rumen digestion}

When soluble leaf protein preparations were fractionated by SDS-PAGE there were two dominant protein bands due to the LSU and the SSU of Rubisco (Plate 3). LSU was susceptible to proteolysis when incubated with strained rumen fluid. The LSU protein band on SDS-PAGE gels was considerably reduced in the 15 min sample and after $1 \mathrm{~h}$ only traces of the LSU band were visible (Plates 3 and 4). SSU resisted proteolysis by rumen microflora (Plate 3).

More detailed information was sought on the effect of PA on the kinetics of degradation of LSU and for these experiments CA was added as an internal standard, after the enzymic 


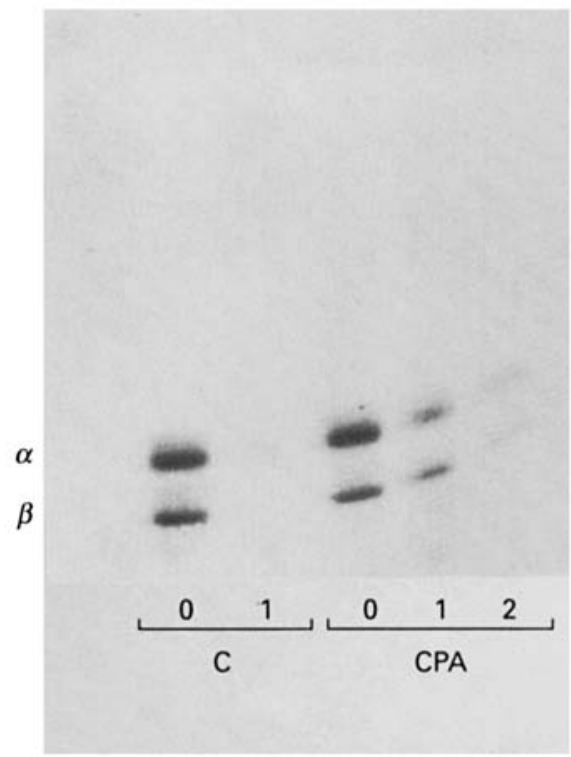

Plate 1. Protection of $\alpha$-casein $(\alpha)$, or $\beta$-casein $(\beta)$ from proteolysis in rumen fluid by added Onobrychis proanthocyanidins. In vitro rumen fluid digests were fractionated by sodium dodecylsulphate (SDS)polyacrylamide gel electrophoresis. Digests contained a final concentration of $1.5 \mathrm{mg} / \mathrm{ml}$ casein only $(\mathrm{C})$ : or casein $1.5 \mathrm{mg} / \mathrm{ml}$ plus Onobrychis PA $0.75 \mathrm{mg} / \mathrm{ml}(\mathrm{CPA})$. Samples $(100 \mu \mathrm{l})$ were removed from each digestion after $0 \mathrm{~h}$, $1 \mathrm{~h}$ and $2 \mathrm{~h}$, diluted with an equal volume of SDS buffer, frozen and later heat denatured. Portions $(5 \mu \mathrm{l})$ of the denatured protein solutions were loaded on each lane. For details, see p. 949.

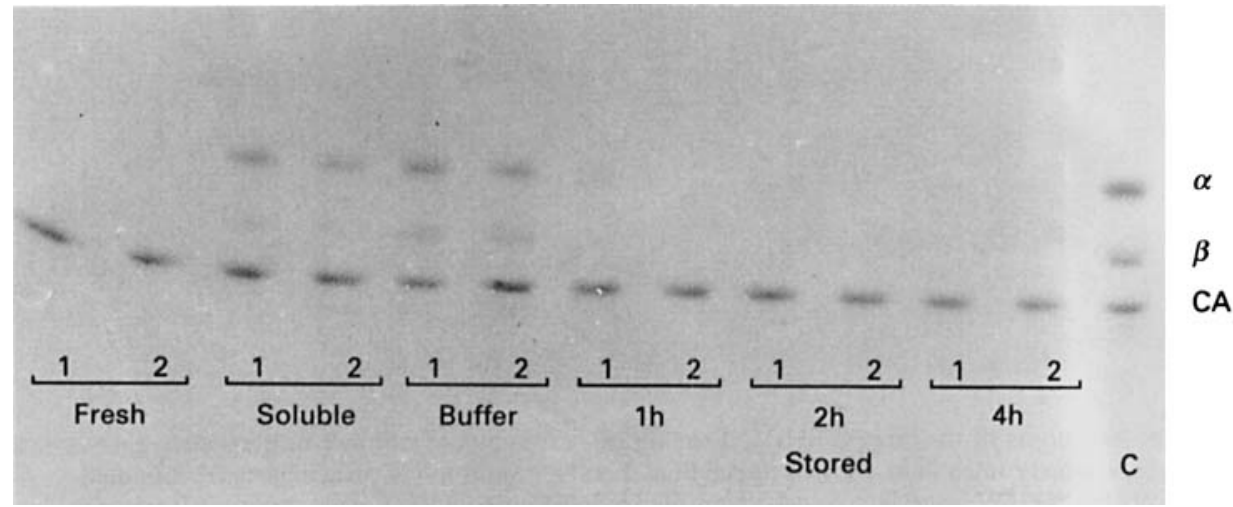

Plate 2. The stability and localization of the proteolytic activity in strained rumen fluid. In vitro rumen fluid digests were fractionated by sodium dodecylsulphate (SDS)-polyacrylamide gel electrophoresis. Digests contained casein and freshly strained rumen fluid (Fresh), or rumen fluid which had been centrifuged at $5000 \mathrm{~g}$ for $10 \mathrm{~min}$ and then filtered through a $0.4 \mu \mathrm{m}$ filter (Soluble); or McDougall's (1948) artificial saliva alone (Buffer); or strained rumen fluid which had been stored anaerobically at $39^{\circ}$ for 1,2 or $4 \mathrm{~h}$ before the addition of casein (stored $1 \mathrm{~h}, 2 \mathrm{~h}, 4 \mathrm{~h}$ respectively). A control digestion (C) contained casein and strained rumen fluid that had been boiled. Samples $(100 \mu \mathrm{l})$ were removed from each digestion after $\mathrm{l} \mathrm{h}$ and $2 \mathrm{~h}$, diluted with an equal volume of SDS buffer containing the internal protein standard carbonic anhydrase (CA;EC 4.2.1.1), frozen, and later heat denatured. Portions $(5 \mu l)$ of the denatured protein solutions were loaded on each lane. 


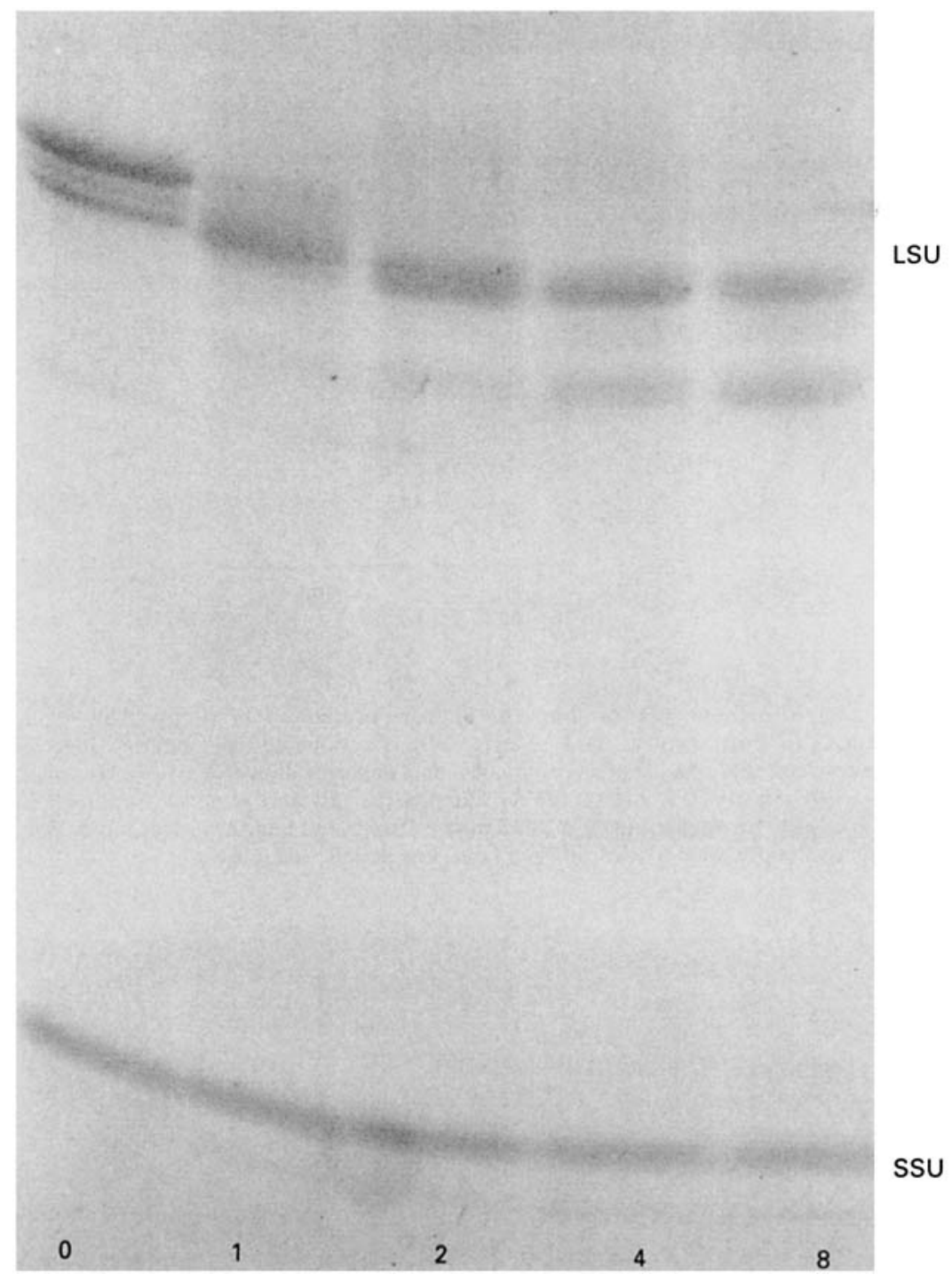

Plate 3. The hydrolysis of the large (LSU) and small (SSU) subunits of ribulose bisphosphate carboxylase ( $E C$ 4.1.1.39) in strained rumen fluid. In vitro rumen fluid digests of soluble leaf protein were fractionated by sodium dodecylsulphate (SDS)-polyacrylamide gel electrophoresis. Samples $(100 \mu 1)$ were removed from each digestion after the indicated time interval (h), diluted with an equal volume of SDS buffer, frozen and later heat denatured. Portions $(5 \mu \mathrm{l})$ of the denatured protein solutions, containing $7.5 \mu \mathrm{g}$ soluble leaf protein at zero time, were loaded on each lane.

reaction was halted. The addition of Onobrychis PA to soluble leaf protein, at a PA:protein ratio of $1: 2$ before incubation in strained rumen fluid, significantly reduced the rate of proteolysis of LSU (Plate 5). After incubation for $2 \mathrm{~h}$ in strained rumen fluid, LSU was substantially undegraded in the presence of PA (Plate 5), compared with LSU incubated in the absence of added PA (Plate 4).

The inhibition of proteolysis by PA was affected by the PA:protein ratio. In experiments designed to examine this effect the Onobrychis PA:protein ratio was varied from 1:1 to 


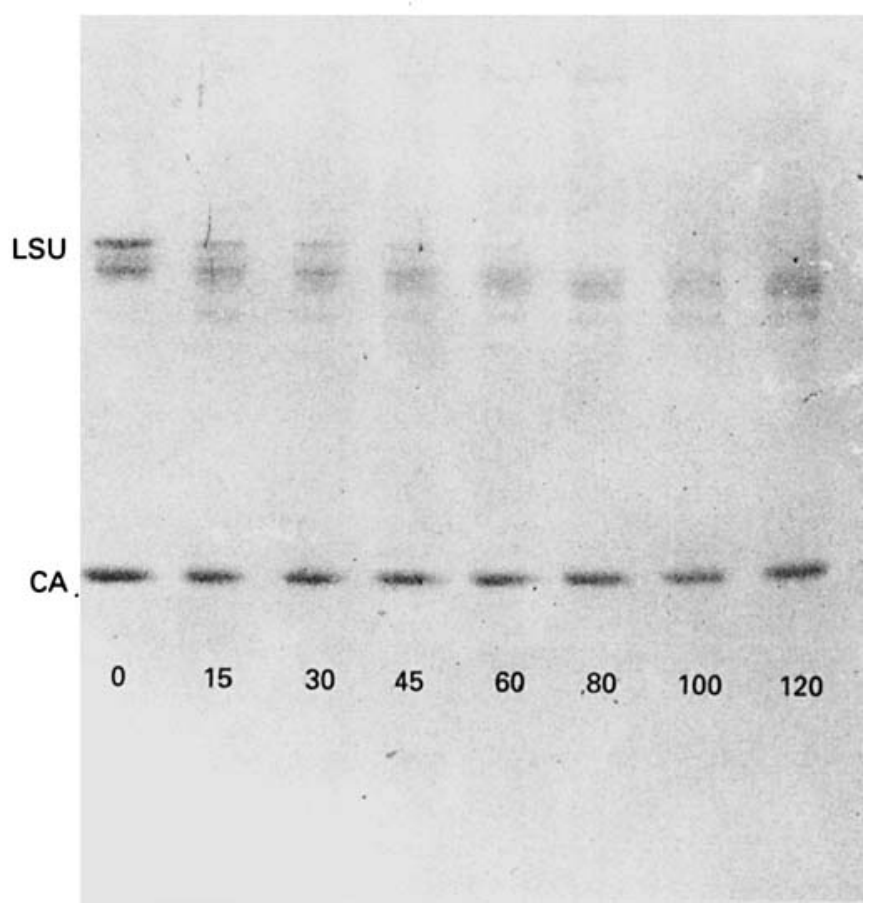

Plate 4. The hydrolysis of the large subunit (LSU) of ribulose bisphosphate carboxylase (EC 4.1.1.39) in rumen fluid. In vitro rumen fluid digests were fractionated by sodium dodecylsulphate (SDS)-polyacrylamide gel electrophoresis. Digests contained a final concentration of $1.5 \mathrm{mg} / \mathrm{ml}$ soluble leaf protein only. Samples $(100 \mu \mathrm{l})$ were removed from each digestion after the indicated time-intervals (min), diluted with an equal volume of SDS buffer containing carbonic anhydrase (CA; EC 4.2.1.1), frozen and later heat-denatured. Portions $(5 \mu 1)$ of the denatured protein solutions, containing $7.5 \mu \mathrm{g}$ soluble leaf protein at zero time, and $0.49 \mu \mathrm{g}$ of the internal standard, CA, were loaded on each lane.

$1: 20$, and the rate of hydrolysis of LSU quantified by densitometry of the LSU band on SDS-PAGE gels.

The rate of hydrolysis of LSU, when the Onobrychis PA:protein ratio was 1:2 or 1:1, was significantly less than the PA-free control, and the rate of digestion of LSU was decreased by between 3 - and 20 -fold (Table 1 ).

Despite rigorous control of the animal diet and the sampling of rumen fluid, the proteolytic activity of the rumen fluid varied between experiments. The rate of digestion of the PA-free control is inversely proportional to the concentration of protease, hence the concentration of protease in Expt 1 was approximately half that of Expt 2 (Table 1). In Expt 1 the rate of proteolysis of LSU in digestion mixtures with Onobrychis PA:protein ratios of $1: 5,1: 10$, or $1: 20$ were not significantly different from the PA-free control (Table 1). In Expt 2 there was significant inhibition of the rate of hydrolysis $(P<0.001)$ with PA: protein ratios greater than $1: 10$.

\section{The effects of PA purified from different plant species on the proteolysis of LSU during in vitro rumen digestion}

The addition of PA from the different species to soluble leaf protein to give PA:protein ratios of $1: 5$ reduced the rate of proteolysis of LSU, compared with the rate of proteolysis in the absence of added PA (Fig. 1, Table 2). In these experiments the rate of hydrolysis 


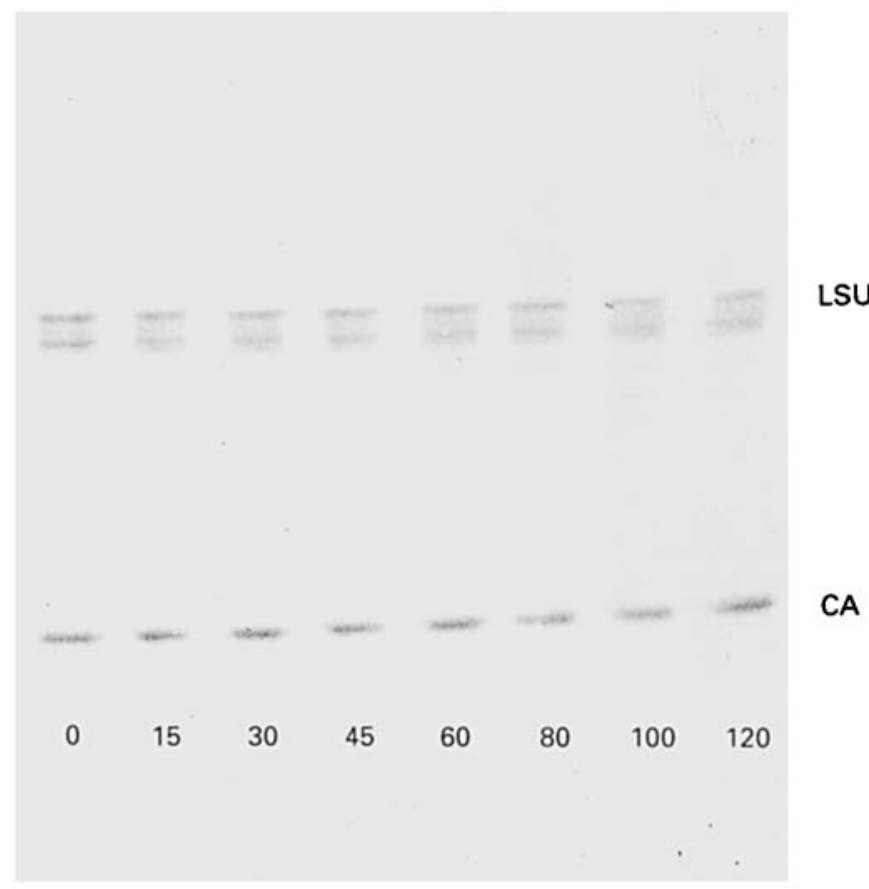

Plate 5. The protection of the large subunit (LSU) of ribulose bisphosphate carboxylase $(E C 4.1 .1 .39)$ from proteolysis in rumen fluid by added proanthocyanidins (PA). In vitro rumen fluid digests were fractionated by sodium dodecylsulphate (SDS)-polyacrylamide gel electrophoresis. Digests contained a final concentration of $1.5 \mathrm{mg} / \mathrm{ml}$ soluble leaf protein plus Onobrychis PA $(0.75 \mathrm{mg} / \mathrm{ml})$. Samples were taken from each digestion after the indicated time (min), diluted with an equal volume of SDS buffer containing carbonic anhydrase (CA;EC 4.2.1.1), frozen and later denatured. Portions ( $5 \mu 1)$ of the denatured protein solutions, containing $7.5 \mu \mathrm{g}$ soluble leaf protein at zero time, and $0.49 \mu \mathrm{g}$ of the internal standard, CA, were loaded on each lane.

Table 1. The effect of the concentration of Onobrychis proanthocyanidins $(P A)$ on the rate of hydrolysis of the large subunit (LSU) of ribulose bisphosphate carboxylase (EC 4.1.1.39)*

\begin{tabular}{|c|c|c|c|c|c|c|}
\hline \multirow[b]{3}{*}{ PA: protein ratio } & \multicolumn{6}{|c|}{ Rate of hydrolysis $\left(\mathrm{min}^{-1} \times 10^{3}\right) \dagger$} \\
\hline & \multicolumn{3}{|c|}{ Experiment 1} & \multicolumn{3}{|c|}{ Experiment 2} \\
\hline & Rate & $\mathrm{SE}$ & $P$ valuet & Rate & $\mathrm{SE}$ & $P$ value \\
\hline No PA & $13 \cdot 3$ & $2 \cdot 0$ & $<0.001$ & $33 \cdot 7$ & $5 \cdot 8$ & $<0.001$ \\
\hline $1: 20$ & $4 \cdot 8$ & $2 \cdot 6$ & 0.087 & $18 \cdot 1$ & $2 \cdot 7$ & $<0.001$ \\
\hline $1: 10$ & $11 \cdot 3$ & 0.9 & $<0.001$ & $14 \cdot 8$ & $2 \cdot 4$ & $<0.001$ \\
\hline $1: 5$ & $12 \cdot 2$ & 1.9 & $<0.001$ & $17 \cdot 2$ & $2 \cdot 5$ & $<0.001$ \\
\hline $1: 2$ & $4 \cdot 6$ & $1 \cdot 0$ & $<0.001$ & 1.6 & $1 \cdot 1$ & $0 \cdot 183$ \\
\hline $1: 1$ & $0 \cdot 2$ & $1 \cdot 3$ & 0.865 & $3 \cdot 8$ & $1 \cdot 6$ & 0.037 \\
\hline
\end{tabular}

* For details of procedures, see p. 949.

$\dagger$ Rate of hydrolysis is the slope of the simple linear regression of $\log _{e}$ (normalized LSU area) v. time. Six degrees of freedom were associated with the calculation of SE of each slope.

$\ddagger$ The statistical significance of each regression is indicated by the $P$ value for variance ratio from simple linear regression. 


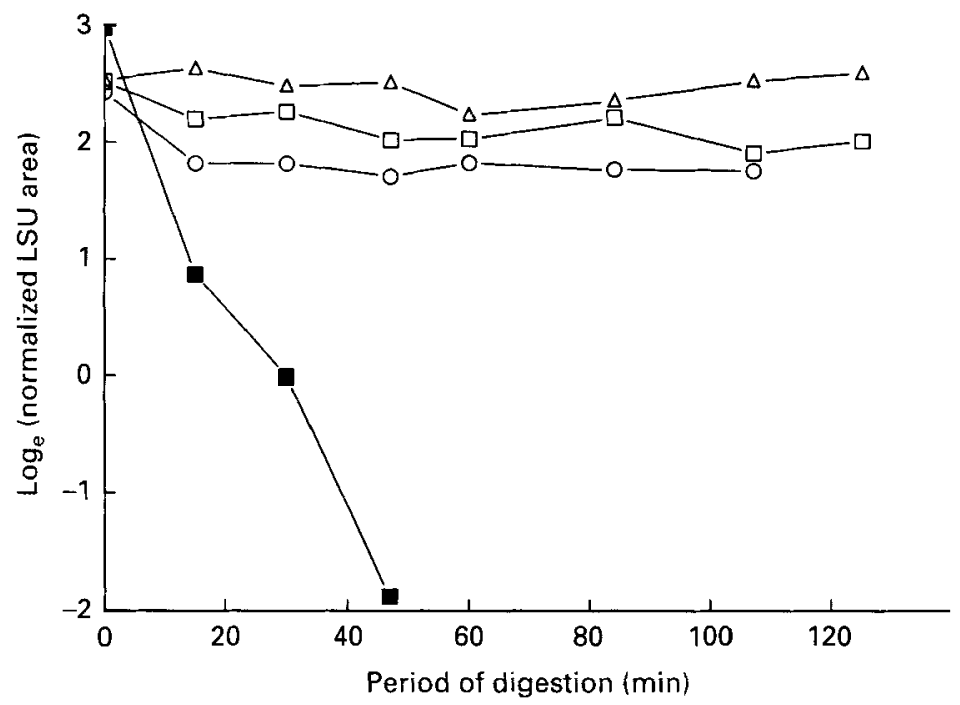

Fig. 1. The protection of the large subunit (LSU) of ribulose bisphosphate carboxylase $(E C 4.1 .1 .39)$ from proteolysis in rumen fluid by added proanthocyanidins (PA). In vitro digestion and electrophoresis conditions were as for Plate 4, except that PA purified from the indicated species was added to give a PA:protein ratio of 1:5. For clarity, only the effects of three representative PA are shown; Coronilla varia $(\triangle)$, Dorycnium rectum $(\square)$, Hedysarum coronarium (O), or no added PA ( $\square$ ). Complete results are shown in Expt 1 (Table 2).

Table 2. The effect of the source of proanthocyanidins $(P A)$, added at a fixed tannin: protein ratio of 1:5 on the rate of hydrolysis of the large subunit ( $L S U$ ) of ribulose bisphosphate carboxylase (EC 4.1.1.39)*

(Digestions contained soluble leaf protein and PA purified from the indicated species to give a PA: protein ratio of $1: 5$ )

\begin{tabular}{|c|c|c|c|c|c|c|}
\hline \multirow[b]{3}{*}{ Source of PA } & \multicolumn{6}{|c|}{ Rate of hydrolysis $\left(\mathrm{min}^{-1} \times 10^{3}\right) \dagger$} \\
\hline & \multicolumn{3}{|c|}{ Experiment 3} & \multicolumn{3}{|c|}{ Experiment 4} \\
\hline & Rate & $\mathrm{SE}$ & $P$ value $\ddagger$ & Rate & $\mathrm{SE}$ & $P$ value $\ddagger$ \\
\hline None & $20 \cdot 5$ & $4 \cdot 4$ & $<0.001$ & $12 \cdot 7$ & $2 \cdot 3$ & 0.002 \\
\hline Coronilla varia & $1 \cdot 4$ & 0.9 & $0 \cdot 150$ & $1 \cdot 3$ & $1 \cdot 1$ & 0.256 \\
\hline Dorycnium rectum & $1 \cdot 0$ & 0.9 & $0 \cdot 272$ & 1.8 & $1 \cdot 0$ & 0.090 \\
\hline Hedysarum coronarium & -1.7 & $0 \cdot 3$ & $<0.001$ & $-1 \cdot 8$ & 1.6 & 0.270 \\
\hline Lotus corniculatus & 0.3 & 1.2 & $0 \cdot 060$ & 1.6 & 0.8 & 0.077 \\
\hline Lotus pedunculatus & 70 & 0.9 & $<0.001$ & $-1 \cdot 1$ & $1 \cdot 0$ & 0.278 \\
\hline Onobrychis viciifolia & $4 \cdot 5$ & $1 \cdot 1$ & 0.002 & -0.6 & $1 \cdot 4$ & 0.698 \\
\hline Trifolium arvense & 40 & $1 \cdot 0$ & 0.003 & 0.9 & $1 \cdot 3$ & 0.497 \\
\hline
\end{tabular}

* For details of procedures, see p. 949.

$\uparrow$ Rate of hydrolysis is the slope of the simple linear regression of $\log _{e}$ (normalized LSU area) $r$. time. Six degrees of freedom were associated with the calculation of SE of each slope.

+ The statistical significance of each regression is indicated by the $P$ value for variance ratio from simple linear regression.

of the PA-free controls, and hence the protease concentration in the rumen fluid, was greater in Expt 3 than Expt 4; however, the trend in the data was similar in both experiments. Rates of hydrolysis were significantly reduced $(P<0 \cdot 001)$ by all PA compared with the PA-free control. 


\section{DISCUSSION}

Previous studies have shown that casein is rapidly hydrolysed by rumen microflora whereas bovine serum albumin is resistant (Mangan, 1972; Spencer et al. 1988 b; Broderick \& Clayton, 1992). Results presented here show that PA from forage legumes inhibit the proteolysis of susceptible proteins such as casein and the LSU of Rubisco by rumen microflora in vitro at $\mathrm{pH} 6 \cdot 8$.

The observation that the proteolytic activity of the rumen fluid was removed by centrifugation and microfiltration indicates that the proteases are firmly attached to the microflora and not distributed homogenously in the soluble phase of the rumen. This implies that colonization of leaf debris by rumen microflora may be a prerequisite for digestion of particulate leaf material. PA localized in leaf particles may impede colonization since local concentrations of PA in disrupted leaf material may be much higher than the average concentration of homogenous solutions used in these experiments. It has been shown that colonization of leaf tissues by rumen bacteria is reduced if the tissues contain high levels of PA (Chiquette et al. 1988).

PA are multidentate ligands, able to bind simultaneously at more than one site on a protein surface, initially by hydrogen bonding and hydrophobic interactions, and later through covalent interactions (Zucker, 1983; Spencer et al. 1988a). The initial hydrogen bonding may be dynamic, with individual linkages being continuously broken and reformed randomly (McLeod, 1974). This interaction may occur between PA and proteolytic enzymes or dietary protein and may inhibit proteolysis due to steric interference with the binding of the protease with susceptible sites on the dietary protein (McManus et al. 1981) or by direct inhibition of the proteolytic enzymes (Kumar \& Singh, 1984).

The degree of bonding between PA and protein is dependent on the type of protein as well as the type of PA (Martin \& Martin, 1983; Zucker, 1983; Asquith \& Butler, 1986; Horigome et al. 1988). PA from different species of forage legumes have been reported to have differing molecular weights and chemical compositions (Jones et al. 1976), and this may be expected to affect the interaction between PA and protein. Further experiments were carried out to examine the effect of PA purified from different species on the rate of proteolysis of LSU in in vitro rumen digestions. PA from all forage legumes tested significantly inhibited the hydrolysis of LSU; however, no significant differences were detected between the effects of different PA.

These results highlight the nutritional significance of PA-containing forages. The reduction in the rate of proteolysis in vitro may be of importance in ruminant nutrition. Up to $30 \%$ of the dietary protein may be effectively lost to the animal through its conversion to ammonia in the rumen and subsequent excretion (Barry \& Manley, 1984; Barry et al. $1986 \mathrm{~b}$ ). Diets with moderate levels of PA $(<50 \mathrm{~g} / \mathrm{kg} \mathrm{DM})$ increase the absorption of nonammonia $\mathrm{N}$ in the small intestine, without compromising voluntary intake and digestibility (Purchas \& Keogh, 1984). Diets with high levels of PA (100-180 g/kg DM) tend to have adverse effects on the ruminant, including reductions in voluntary intake, digestibility, metabolizable energy intake and fat deposition (Barry \& Duncan, 1984; Barry et al. 1986 a; Chiquette et al. 1988; Kumar \& Vaithiyanathan, 1990).

Our experiments have shown that the inhibitory effect on proteolysis occurs for PA:protein ratios above about 1:5. Forage legumes containing between 20 and $50 \mathrm{gPA} / \mathrm{kg} \mathrm{DM}$ are encountered growing under field conditions, and would have PA: soluble protein ratios in excess of those required to inhibit proteolysis. It is likely that ruminants grazing such forages benefit from increased protein absorption due to reduced rumen hydrolysis of leaf protein. 
The authors would like to thank Mr W. J. Müller (INRE, Biometrics Unit, CSIRO, Canberra), for carrying out the statistical analysis of the data. This work was supported by a grant from the Australian Wool Research and Development Corporation, and the Australian Meat Research Corporation.

\section{REFERENCES}

Asquith, T. N. \& Butler, L. G. (1986). Interactions of condensed tannins with selected proteins. Phytochemistry 25, 1591-1593.

Barry, T. N., Allsop, T. F. \& Redekopp, C. (1986a). The role of condensed tannins in the nutritional value of Lotus pedunculatus for sheep. British Journal of Nutrition 56, 607-614.

Barry, T. N. \& Duncan, S. J. (1984). The role of condensed tannins in the nutritional value of Lotus pedunculatus for sheep. 1. Voluntary intake. British Journal of Nutrition 51, 485-491.

Barry, T. N. \& Manley, T. R. (1984). The role of condensed tannins in the nutritional value of Lotus peduncularus for sheep. 2. Quantitative digestion of carbohydrates and proteins. British Journal of Nutrition 51, $493-504$.

Barry, T. N. \& Manley, T. R. (1986). Interrelationships between the concentrations of total condensed tannin, free condensed tannin and lignin in Lotus sp. and their possible consequences in ruminant nutrition. Journal of the Science of Food and Agriculture 37, 248-254.

Barry, T. N., Manley, T. R. \& Duncan, S. J. (1986 b). The role of condensed tannins in the nutritional value of Lotus pedunculatus for sheep. 4. Sites of carbohydrate and protein digestion as influenced by dietary reactive tannin concentration. British Journal of Nutrition 55, 123-137.

Broderick, G. A. \& Clayton, M. K. (1992). Rumen protein degradation rates estimated by non-linear regression analysis of Michaelis-Menten in vitro data. British Journal of Nutrition 67, 27-42.

Chiquette, J., Cheng, K. J., Costerton, J. W. \& Milligan, L. P. (1988). Effect of tannins on the digestibility of two isosynthetic strains of birdsfoot trefoil (Lotus corniculatus L.) using in vitro and in sacco techniques. Canadian Joumal of Animal Science 68, 751-760.

Gray, J. C. (1982). Use of proteolytic inhibitors during isolation of plastid proteins. In Methods in Chloroplast Molecular Biology, pp. 1093-1102 [M. Edelman, editor]. Dublin: Elsevier Biomedical Press.

Horigome, T., Kumar, R. \& Okamoto, K. (1988). Effects of condensed tannins prepared from leaves of fodder plants on digestive emzymes in vitro and in the intestine of rats. British Journal of Nutrition 60, $275-285$.

Jones, W. T., Broadhurst, R. B. \& Lyttleton, J. W. (1976). The condensed tannins of pasture legume species. Phytochemistry 15, 1407-1409.

Kristiansen, K. N. (1984). Biosynthesis of proanthocyanidins in barley: genetic control of the conversion of dihydroquercetin to catechin and procyanidins. Carlsberg Research Communications 49, 503-524.

Kumar, R. \& Singh, M. (1984). Tannins, their adverse role in ruminant nutrition. Journal of Agricultural and Food Chemistry 32, 447-453.

Kumar, R. \& Vaithiyanathan, S. (1990). Occurrence, nutritional significance and effect on animal productivity of tannins in tree leaves. Animal Feed Science and Technology 30, 21-38.

Laemmli, U. K. \& Favre, M. (1973). Maturation of the head of bacteriophage T4. 1. DNA packaging events. Journal of Molecular Biology 80, 575-599.

McDougall, E. I. (1948). Studies on ruminant saliva. 1. The composition and output of sheep's saliva. Biochemical Journal 43, 99-109.

McLeod, M. N. (1974). Plant tannins - their role in forage quality. Nutrition Abstracts and Review' 44, 803-815.

McManus, J. P., Davis, K. G., Lilley, T. H. \& Haslam, E. (1981). The association of proteins with polyphenols. Journal of the Chemical Society Chemical Communications 7, 309-311.

Mabry, T. J., Markham, K. R. \& Thomas, M. B. (1970). The Systematic Identification of Flavonoids, pp. 3-14. New York: Springer-Verlag.

Mangan, J. L. (1972). Quantitation studies on nitrogen metabolism in the bovine rumen. The rate of proteolysis of casein and ovalbumin and the release and metabolism of free amino groups. British Journal of Nutrition 27 , 261 283.

Martin, J. S. \& Martin, M. M. (1983). Tannin assays in ecological studies: precipitation of ribulose-1,5,bisphosphate carboxylase/oxygenase by tannic acid, quebracho and oak foliage extracts. Journal of Chemical Ecology 9, 285-294.

Mole, S. \& Waterman, P. G. (1985). Stimulatory effects of tannins and cholic acid on tryptic hydrolysis of proteins: ecological implications. Journal of Chemical Ecology 11, 1323-1332.

Petersen, J. C. \& Hills, N. S. (1991). Enzyme inhibition by Sericea Lespedeza tannins and the use of supplements to restore activity. Crop Science 31, 827-832.

Purchas, R. W. \& Keogh, R. G. (1984). Fatness of lambs grazed on 'Grasslands Maku' lotus and 'Grasslands Huia' white clover. Proceedings of the New Zealand Society of Animal Production 44, 219-221.

Rumbaugh, M. D. (1985). Breeding bloat-safe cultivars of bloat-causing legumes. In Forage Legumes for Energyefficient Animal Production. Proceedings of the Trilateral Workshop, Paimerston North, N.Z., pp. $238-245[\mathrm{R}$. F. Barnes, P. R. Ball, R. W. Bringham, G. C. Marten and D. J. Minston, editors]. Washington, DC: USDA. 
Spencer, C. M., Ya, C., Martin, R., Gaffney, S. H., Goulding, P. N., Magnolato, D., Lilley, T. H. \& Haslam, E. (1988a). Polyphenol complexation - some thoughts and observations. Phytochemistry 27, 2397-2409.

Spencer, D., Higgins, T. J. V., Freer, M., Dove, H. \& Coombe, J. B. (1988b). Monitoring the fate of dietary proteins in rumen fluid using gel electrophoresis. British Journal of Nutrition 60, 241-247.

Tagari, H., Henis, Y. \& Volcani, R. (1965). Effect of carob pod extract on cellulolysis, proteolysis, deamination, and protein biosynthesis in an artificial rumen. Applied Microbiology 13, 437-442.

Van Hoven, W. \& Furstenburg, D. (1992). The use of purified condensed tannin as a reference in determining its influence on rumen fermentation. Comparative Biochemistry and Physiology 101A, 381-385.

Zucker, W. V. (1983). Tannins: does structure determine function? An ecological perspective. American Naturalist 121, 335-365. 